2) Hassler, Rice and Leeman: Investigations on the Recovery of Oil from Sandstones by Gas Drive, Trans. A.I.M.E., 1936

3) Dunlap: Influence of Connate Water on Permeability of Sands to Oil, Trans. A.I.M. E., 1938

4) Leverett: Flow of Oil-Water Mixtures through Unconsolidated Sands, Trans. A.I. M.E.. 1939

5) Botset: Flow of Gas-Liquid Mixtures through Consolidated Sands, Trans. A.I.M.E., 1940

6) Morse, Terwilliger and Yuster: Relative Permeability Measurements on Small Core Samples, Producers Monthly, August, 1947

7) Henderson and Yuster: Relative Permeability Studies, Producers Monthly, January, 1948

8) Henderson and Meldrum : Progress Report on Multiphase-flow Studies, Producers Monthly, March, 1949

9) Muskat: Physical Principles of Oil Production, 1949

10) Pirson: Elements of Oil Reservoir Engineering, 1950

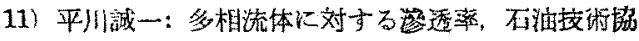
会誌，第 16 笪， 2 号(昭和 26 年 3 月)
12) Brownscombe. Slobod and Caudle: Laboratory Determination of Relative Permeability, A.P.I., 1949

13) Gates and Lietz: Relative Permeabilities of California Cores by the Capillary-pressure Method, A.P.I., 1950

14) Osoba, Richardson, Kerver, Hafford and Blair : Laboratory Measurements of Relative Permeability, Journal of Petro. Technology, Feb., 1951

15) Geffen, Owens, Parrish and Morse: Experimental Investigation of Factors affecting Laboratory Relative Permeability Measurements, Journal of Petro. Technology, April, 1951

16) Caudle, Slobod and Brownscombe: Further Developments in the Laboratory Determination of Relative Permeability, Journal of Petro. Technology, May, 1951

17) Richardson, Kerver, Hafford and Osoba : Laboratory Determination of Relative Permeability, Journal of Petro. Technology, August, 1952

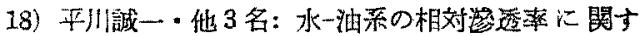

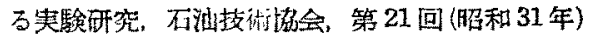

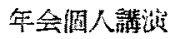

\title{
$3,000 \mathrm{~m}$ 井掘籢一般概 況*
}

$$
\text { 况下践夫** }
$$

帝国石油侏式会社秋田鉝業所八橋高野 R 113 昂井飞括 いて, 深度 $3,000 \mathrm{~m}$ 掘整朴が昭和 30 年 4 月 29 日開坑

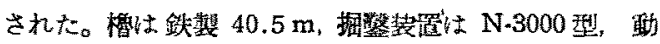

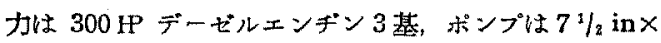
15 in $\mathrm{OH}$ 型 1 基, $7 \%$ in $\times 14$ in エムスコ 1 基である。 上下この措戸の作業経過を記す。

\section{(1) ユニタイスコンダクターパイプ段跬}

コンダタター掘はサタションピシトを使用せず，マッ

ドスクリーンを通して正規なフローラインとした。また

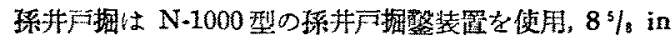
C.P.Kて No. 1 および No. 2 の 2 本安設置す。

\section{(2) コンダクターパイフ捙入のための掘進}

予定深庭 3,000 m として昭和 30年 4 月 29 日開坑す。 $10^{\frac{1}{2}}$ in $\times 13^{\frac{1}{2} \text { in }}$ in $\times 16$ in と 3 段掘りとし，205 m まて

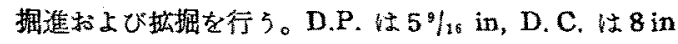

\footnotetext{
*第 21 回楼会㑭人㒛㟨

**策石

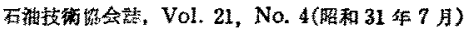

$6 \mathrm{~m} 2$ 本を健用，荷重 $2,000 \sim 3,000 \mathrm{lb}$ にて掘進，倾斜 は $205 \mathrm{~m}$ にて $0^{\circ}$ ，泥承は比重 $1.14 ，$ 粘性 45 秒であ る。

使用ビット 掘谁 $10^{1} / 2$ in LB, 1 丁

㹡据 $13^{1 / 2}$ in $\mathrm{MDB}, 1 \mathrm{丁}, 16$ in MDB, $1 丁$

(3) $13 \%$ in コンダタターパイプ捅入

13 3/s in C.P.を $190 \mathrm{~m} 40$ まで降下，七メンチング を施行す。C.P. 降下状况は非常に良好であつた。セれ ンチングはハリバートン型セメンチングュニシトを使 用，2栓式にてセメント 300 管を送り込むも坑口まで掦 らず，坑口管外より 2 in T.P. 老降下，110袋を注入坑 口までせメントを充埃す。管内テストは $40 \mathrm{~kg} / \mathrm{cm}^{2} 20$ 分，管外テストは $20 \mathrm{~kg} / \mathrm{cm}^{2} 20$ 分を旅行す。これ纯、 ずれも完全と银められた。

(4) $1,600 \mathrm{~m}$ までの $10 \%$ in ビツト掘僬

コンダクターをツト後, 開坑式括上び機㭜性能テスト 


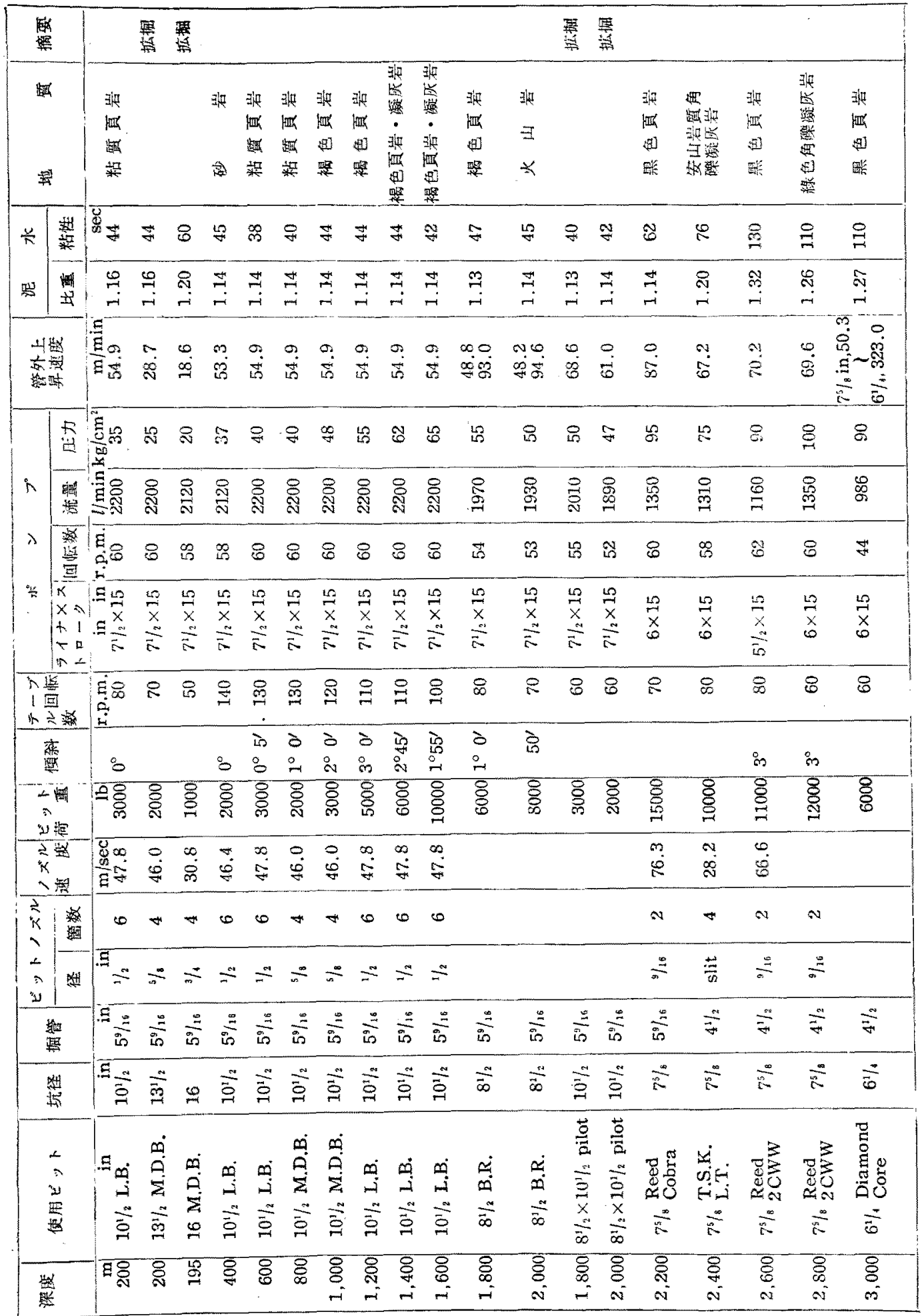


を施行，5月16日 $10^{2} / 2$ in LB とて相進を再開した。 八槚では一般に $1,200 \mathrm{~m}$ 附近までは M.D.B. 在敒用す るのが通例であるが，本扑では坑口上りカッタータイプ

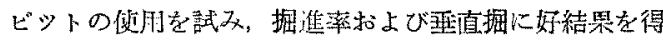
た。㨄管は $5 \%$ in $\times 6 \mathrm{~m}$, ドりルカラーは 8 in $\times 6 \mathrm{~m} 2$ 本 +7 in $\times 6 \mathrm{~m} 5$ 本夌使川， $1,000 \mathrm{~m}$ 附近までは特に候

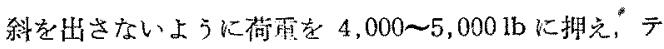
ーブル回転を100〜200 回枟て掘進，540 m で $0^{\circ}, 800$ $\mathrm{m}$ で $1^{\circ}, 1,000 \mathrm{~m}$ て $1^{\circ} 30^{\prime}$ と好結柦を得太。 $1,000 \mathrm{~m}$ 以下は荷㕣 $9,000 \sim 10,000 \mathrm{lb} / \mathrm{in}^{2}$ て掘進， $1,300 \mathrm{~m}$ K て $3^{\circ} 45^{\prime}$ と若干增的家昧々なつたため，スタビライガー の位置变更等により自然ここれを矯正し， $1,600 \mathrm{~m}$ にて 1`55 とならた。ビットは $10^{1} \%$ in LB が主休でするが 大体 1 ビット 1 日程度の伐用状况となり，掘進率は2 $5 \mathrm{~m} / \mathrm{H}$ である。またカッタービツトはブレードビットに

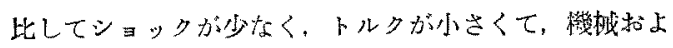

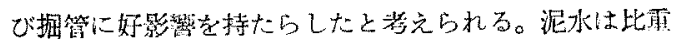
1.14, 粘性 40 秒前媵に維持, CMC マッドの特性にて ゲル化少なく，ボンブ王の軽減，張竹きの減少またシ ヨーイング等に好繥岩を得た。1,100 m 以下の VII， VIII, IX 層はシヨーイングにより確琶することができ た。またコンダクター以下はベントナイトを倞㶲せず， CMC 泥水を使用していたが， $1,400 \mathrm{~m}$ 上り迹次 low lime mud K移行していらた。 5 月 16 H 10\% in LB にて $205 \mathrm{~m}$ 上り掘准妾始めてから，6月 2 日 $1,600 \mathrm{~m}$ に達するまで38日を装した。

(5) $1,600 \sim 1,800 \mathrm{~m} 81 / 2$ in 掘および D.S.T.

1,600 1,680 m 屯で $81 / 2$ in LB にてピット掘, 以 下 $1,800 \mathrm{~m}$ まで $81 / 2$ in BRHにてオールコフリング を行つた。寺の闌 $1,560 \mathrm{~m}$ 層出よび $1,600 \mathrm{~m}$ 周を D. S.T. 7 回施行寸るも，ガス量最高 $200 \mathrm{~m}^{3}$ 位，探取液

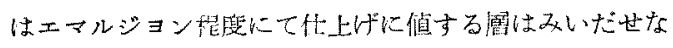
からた。

(6) $1,600 \sim 2,005 \mathrm{~m}$ 問のコア掘および拡掘

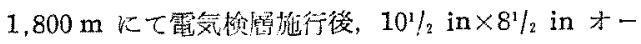
プナー(2カッター)にて $1.600 \mathrm{~m}$ より $1,790 \mathrm{~m}$ まて 拨掘を行い, 以下 $2,005 \mathrm{~m}$ まで $8 \frac{1}{2}$ in BRH にて才

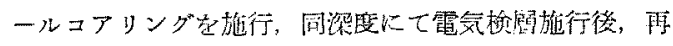

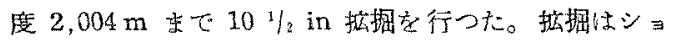
ック怙よびトルク犬なるため、テーブル回転を 40〜50 に落し、ドリルカラー折損等なきよ5に注意した。地冥

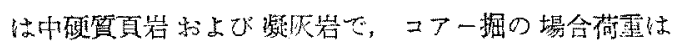
6,000 9,000 lb、テープル 70 r.p.m., ボンプは 2,005 $\mathrm{m}$ まで $7 \frac{1}{2}$ in $\times 15$ in 60 r.p.m., 圧力は $60 \mathrm{~kg} / \mathrm{cm}^{2}$ 程 度である。泥水は low lime CMC mudにて比再 1.14, 粘性 40〜50秒心て崩淕・虺泥等るなく，坑内状況は良
行であつた。

\section{(7) $8 \%$ in 水止管降管作業}

$2,004 \mathrm{~m}$ 屯て $10 \frac{1}{2}$ in 拉㨡後, 玾内状況良好之判断

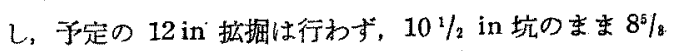
in C.P. 老降下，目的深度 $1.992 \mathrm{~m} 40$ まで異状なく绦 管できた。降管にあたり，ウオークラインは 8 本網を 10 本縦に取直し， $8 \%$ in C.P. 絰荷重 $220,000 \mathrm{lb}$ に対処 した。C.P.は $32 \mathrm{lb}$ と $38 \mathrm{lb}$ 抢よび長权じ・短ねじを゙ 組み台わせて降下，グリップエレベーター・グリップス ハイダーを使用，非常に能率を上げた。C.P.は地上で 2 本継ぎに組み，1本追降の型式で降下したが，降管始 めより終了まで15時間要した。降管にはもちろんVS モーターを使用した。降管前の泥水の比重 1.14, 粘性 40 秒である。

(8) $8 \frac{5}{8}$ in C.P.水止セメンチングおよび水止テスト ハリバートンセメンチングニニット 2 セトを用い, ポルトランドセメント 600 垡盿用, 比重 1.18 とした

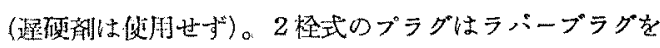

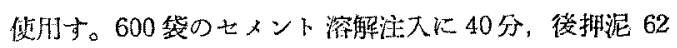
$\mathrm{k} 1$ 压送に 39 分を要した。12時間後にシュラベルジャー 温度測定を施行，七メント上乐の㳭度を確認し，ただる 比紫孔し，遍せメンチング 300 篦を旅行，スクイズセメ ンチンダによりVIII 閻・IX 㬝間に完全なるせパレー ションを䌖成した。水止テスト作業完了後 $5^{9} / 16$ in D.P. 莸 $4 \frac{1}{2}$ in D. P. (DSST) に組替えた。

(9) エンヂン・機诚オーバーホール

$8^{5} / 8$ in C.P. 七ット後オーパーホールを施行，7日間 を要した。

(10) $2,005 \mathrm{~m}$ より $3,000 \mathrm{~m}$ までの掘進

$4 \frac{1}{2}$ in D.C. $6 \mathrm{~m}$ を 19 本倾朋, $7 \%$ in ヒニーズ osc 3丁 ビットにて9月 3 日掘進再開寸。ポンブは 6 in ライナーに入替方, 60 r.p.m. にて圧力は 60〜100 $\mathrm{kg} / \mathrm{cm}^{2}$ である。地刑は $2,140 \mathrm{~m}$ までは硬留凝灰岩にて 掘進率 $2 \mathrm{~m} / \mathrm{H}$, ビシト 1 丁当りの掘進 $5 \mathrm{C} \sim 70 \mathrm{~m} \mathrm{kて}$

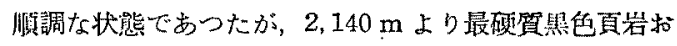

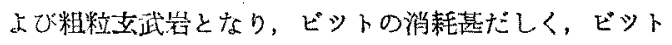
1丁当り 7 $5 \mathrm{~m}, 5 \sim 10 \mathrm{H}$, 以下すべて地唄堅硬のため ビットの消耗䓕だしく，掘進工程が抙れるようになつ た。輸入ヒユーズ拉よびリードビットを相当数使煳した が，主体としては和整 $2 \mathrm{CWW}$ 俅用し，2,972 m 40 步て据進した。同深度以下 $6 \%$ in ダイヤモンドクラウ ンビットを使用し，荷重 $4,000 \sim 6,0001 \mathrm{~b}$ で 40 70

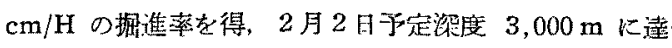
した。開坑の日より280日要した。2,000 $\mathrm{m}$ 以下の掘 進には，坑内状況，ビットの状態判断のため、トルクォ ーターが特心役に立つた。カッターの引擢り，割れ，磿 
耗状況等トルクメーターの指針の鈎きで大体判断するこ

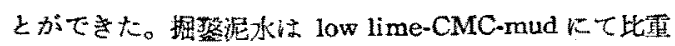
1.14，粘性 40〜45秒で進んだが，2，400 m 附近上りビ

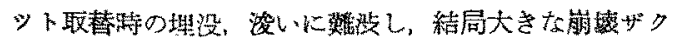
を坑口すで搬出させるため，比雷 $1.28 〜 1.30$, 粘性 60 秒前啳まで上界させ対好した。また $2,778 \mathrm{~m} 40$ 以下は D.P. 抑留防止のため， ローライムエマルジョンマッド そした（5１0\%）。坑底温度はシニランベルジャ一温度 湘定器比て $2,500 \mathrm{~m}$ で $102^{\circ}$, 最高温垡計化て $3,100 \mathrm{~m}$ で $123^{\circ}$ であつた。垤上デッチの泥水の温管は $64 \sim 67^{\circ}$ であつた。

(11) $2,250 \mathrm{~m}$ 前後の D.S.T.

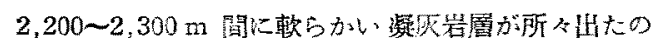
で, 合㖕 7回 D.S.T. 老施行したが，1回成功したのみ

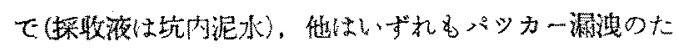
め失敗した。キャリパ一㻢行の結果，崩填のたる，坑保 が平均して 13〜14in.に大きくなつていたのでテスト は数念した。

(12) $2,778 \mathrm{~m} 40$ における D.P. 㧕留

12 月 4 日 $2,778 \mathrm{~m} 40$ に大スポットコフリングのた め $7 \%$ in BRH こアービットを降下, $2.768 \mathrm{~m}$ にて循

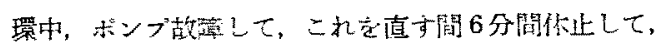

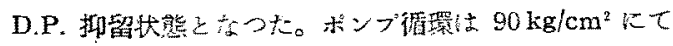

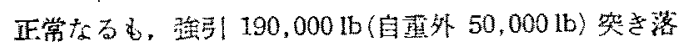

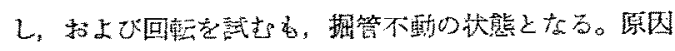

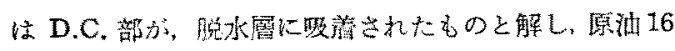
kl t3回に分け D,C. 部に迷込及，强引，突点落しを

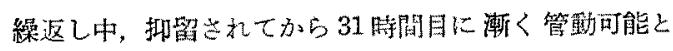
なつた。卆れ以後掘止めまで，泥水はエマルジョンマッ
ドそしだ。

(13) ウオークライン

$1 \%$ in フイラー麻芯 $\times 850 \mathrm{~m} \mathrm{1}$ 条, $1 \%$ in シール

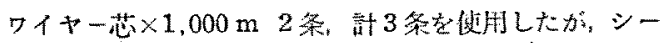
ルワイヤ一芯の方か，径落り・断線已も非常に成維良く

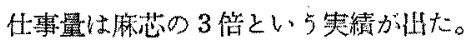

理別䊉上び代慗量

No. $1>17-$ F $\times 850 \mathrm{~m} \quad 13,343 \mathrm{t}-\mathrm{km}$

No. 2 シールワ1ヤ一芯 $\times 1,000 \mathrm{~m}$ $42,573 \mathrm{t}-\mathrm{km}$

No. 3 シールワイヤー芯× $\times 1,000 \mathrm{~m}$ $3,759 \mathrm{t}-\mathrm{km}$ 优事中

(14) ステンレススチールマッドクリーンの成果

当非和いては11月 4 日から，18-8Cr 24 \# ステン

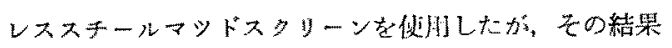

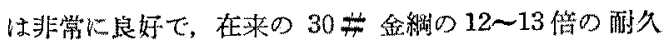

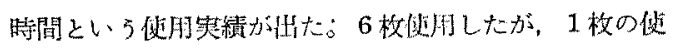

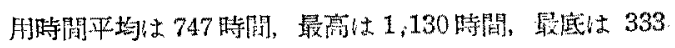
時間ですつた。

\section{(15) 防喷綮置}

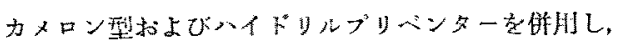
万暗老期した。

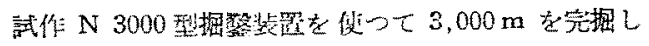

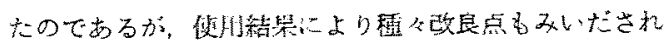

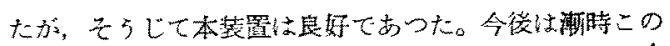

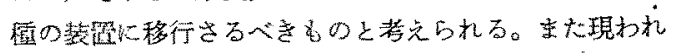

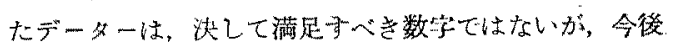
におけるわが国梁据茾の土台在となれば幸いである。

压維機整僙に上る篮ガス量㫮加の1例

\section{泉部行 男*}

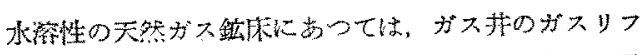

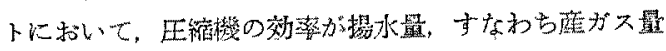

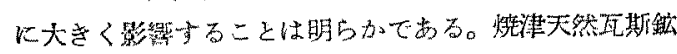

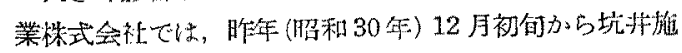

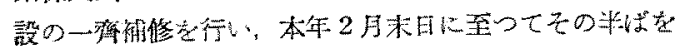
完了した。

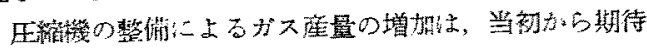

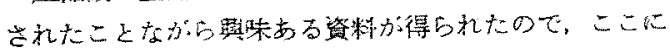

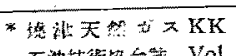

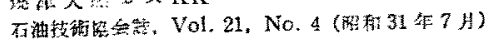

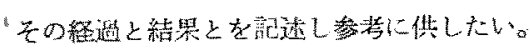

\section{1）整備前の狀況}

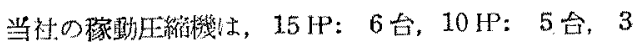

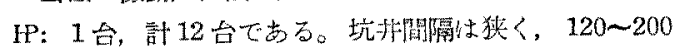

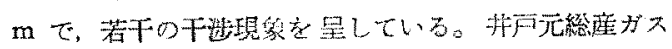

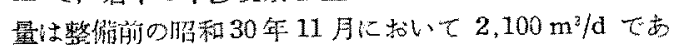
つた。

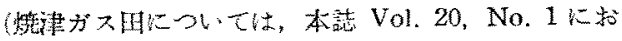
いて伊田一滋氏により詳馀されているので参照された w。 